\title{
TOURISM AS A FACTOR OF SUSTAINABLE DEVELOPMENT OF RURAL AREAS BELONGING TO RUDNIČKA MORAVA
}

\author{
Lela Ristić1, Milan Vujičić², Miljan Lekovic ${ }^{3}$
}

\begin{abstract}
Summary
The paper looks at tourism as an essential component of sustainable development of rural areas belonging to Rudnička Morava territory. The aim of the paper is to point to the role of tourism in the integration of rural areas into the national and international economy based on the analysis of the relevant rural development model and in terms of more efficient endogenous development. The main hypothesis is that rural areas belonging to Rudnicka Morava territory have significant natural and anthropogenic resources for tourism development. However, what lacks is an integrated strategy that would contribute to sustainability and strengthening of the competitiveness of the rural economy. In accordance with the subject of the paper, its aim and the set hypotheses, qualitative, quantitative and SWOT analysis were applied during the research. A survey was conducted in order to obtain positions and feedback from the key actors involved in tourism development. The paper is organized in eight sections. The main result of the research points to the necessity of giving priority to rural tourism development as an essential component of the revitalization of villages and local communities.
\end{abstract}

Key words: sustainable tourism, rural development, tourism products, destination marketing system, Rudnička Morava.

JEL: $018, P 25, Q 19, R 19$.

\section{Introduction}

Tourism is generally considered in scientific literature as an industry that has a sig-

1 Lela Ristić, Ph.D., Associate Professor, University of Kragujevac - Faculty of Economics, Đure Pucara Starog №3, 34000 Kragujevac, Republic of Serbia, Phone: +381 603348719 , E-mail: 1ristic@kg.ac.rs

2 Milan Vujičić, Ph.D., University of Kragujevac - Faculty of Philology and Arts, Jovana Cvijića street bb, 34000 Kragujevac, Republic of Serbia, Phone: +381 603377 404, E-mail: vujicicm@yahoo.com

3 Miljan Leković, Teaching Assistant, University of Kragujevac - Faculty of Hotel Management and Tourism in Vrnjacka Banja, Vojvođanska bb, 36210 Vrnjacka Banja -Vrnjci Spa, Republic of Serbia, Phone: +381 6435823 04, E-mail: $\underline{\text { m.lekovic@kg.ac.rs }}$ 
nificant effect on the economic, social and functional structure of rural areas and as an essential factor in the revitalization and diversification of rural economy (Cozac, 2012; Todorović, Štetić, 2009; Todorović, Bjeljac, 2007; Štetić, Šimičević, 2008; Udovč, Perpar, 2007; Buhalis, Costa, 2006; Pejanović, Vujović, 2008; Bogdanov et al., 2011; Saarinen, Lenao, 2014; Košić et al., 2015). As a matter of fact, those tourist destinations that are distinctive for their preserved and protected nature and unique anthropogenic tourism resources are nowadays considered as the most attractive ones to tourists. Rural areas and their communities have the ability to offer these tourism values and therefore, this is the basis for their tourism potential. The available resources on the territory of Rudnička Morava qualify this microregion to be included in the list of development priorities; furthermore, Rudnička Morava is declared a highly valued region with important natural, cultural and historical resources and a tourism region with distinctive tourist attractions and development potential. Natural and anthropogenic values are characterized by diversity of territorial units of this microregion, as well as their complexity and complementarity. Also, its natural resources represent a solid basis for tourism development. Natural values are especially reflected in beautiful nature, breathtaking landscapes, unique geomorphological features, forests, flora and fauna, rivers and streams, mineral springs, spas, etc. Cultural offer of this microregion is enriched by a series of events and its most authentic traditions are contained in legends, narratives and stories. Sports and recreational activities are a significant motivator of tourist travel in this area. The proximity of cities and roads contribute to the tourism potential and attractiveness of this area.

\section{Research methodology}

For the purpose of analysis and in accordance with the aim of the paper, several scientific methods were applied. The method of analysis and synthesis was applied due to the fact that the research in this paper is based on the key strategic documents in the field of sustainable rural development and tourism, relevant scientific literature and official statistical publications; therefore, it was necessary to make a proper selection, process and analyze written material and the results of previous research in the abovementioned scientific field. The descriptive method was used in terms of the detailed description of the important facts that relate to the sustainable rural development. SWOT (strengths, weaknesses, opportunities, and threats) analysis was used to carry out the strategic analysis of rural areas belonging to Rudnička Morava territory. In order to test the initial hypothesis the method of verification was used. The paper gives special attention to the relationship between theoretical and empirical approach to sustainable rural development. The socio-economic situation in rural areas of Rudnička Morava was identified by conducting primary and secondary research and applying quantitative and qualitative analysis. The paper also identifies strategic steps to be taken in order to strengthen the sustainable development of this microregion through tourism. 


\section{Research results}

\section{Rudnička Morava microregion - location and macroeconomic indicators}

Rudnička Morava microregion belongs to the statistical region of Šumadija and Western Serbia and includes:

- Moravica District: the town of Čačak - 31 villages (Goričani, Katrga, Mršinci, Kukići, Mrčajevci, Bečanj, Bresnica, Zablaće, Baluga Trnavska, Vapa, Donja Gorevnica, Stančići, Mojsinje, Konjevići, Baluga Ljubićska, Donja Trepča, Ostra, Vujetinci, Gornja Trepča, Prislonica, Preljina, Ljubić, Sokolići, Rakova, Trbušani, Vranići, Milićevci, Prijevor, Vidova, Miokovci and Gornja Gorevnica).

- Raška District: the town of Kraljevo - 4 villages (Obrva, Cvetke, Lađevci and Tavnik). Šumadija and Western Serbia statistical region covers an area of $26,493 \mathrm{~km}^{2}$. It consists of 2,112 settlements and the total population in this region is 2,003,118 (Table 1). This Region participates in the GDP of the Republic of Serbia with 19\% (Statistical Office of the Republic of Serbia, 2014b). Average net salary per employee in Sumadija and Western Serbia statistical region compared to the national average and according to data from 2013 is $85.2 \%$, i.e. Moravica District $86.4 \%$ - the Town of Čačak $86.5 \%$ and Raška District 82.3\% - the Town of Kraljevo 85.1\% (Statistical Office of the Republic of Serbia, 2014a).

Table 1. Key macroeconomic indicators of Šumadija and Western Serbia Region - Districts of Moravica and Raška

\begin{tabular}{|l|l|l|l|}
\hline & $\begin{array}{l}\text { Šumadija and } \\
\text { Western Serbia } \\
\text { Region }\end{array}$ & $\begin{array}{l}\text { Moravica } \\
\text { District }\end{array}$ & $\begin{array}{l}\text { Raška } \\
\text { District }\end{array}$ \\
\hline Total area (km) & 26,493 & 3,016 & 3,923 \\
\hline Number of settlements & 2,112 & 206 & 359 \\
\hline Total population & $2,003,118$ & 209,365 & 308,386 \\
\hline Density/km (km $^{2}$ & 76 & 69 & 79 \\
\hline Number of cadastral municipalities & 1,935 & 194 & 305 \\
\hline Agricultural land (\%) & 59.9 & 58.6 & 48.3 \\
\hline Persons employed at some legal entity (\%) & $\mathbf{7 2 . 1}$ & $\mathbf{7 2 . 3}$ & $\mathbf{7 0 . 2}$ \\
\hline Manufacturing industry (\%) & 22.0 & 28.0 & 12.9 \\
\hline Trade (\%) & 7.4 & 8.7 & 7.3 \\
\hline Transportation (\%) & 4.0 & 4.1 & 5.0 \\
\hline Healthcare industry (\%) & 9.7 & 7.8 & 10.3 \\
\hline Education (\%) & 9.9 & 7.1 & 10.7 \\
\hline Entrepreneurs and their employees (\%) & $\mathbf{2 7 . 9}$ & $\mathbf{2 7 . 7}$ & $\mathbf{2 9 . 8}$ \\
\hline
\end{tabular}

Source: According to data published by Statistical Office of the Republic of Serbia, 2014a.

Moravica District covers an area of $3,016 \mathrm{~km}^{2}$. It consists of 206 settlements and its total population is 209,365. There are 194 cadastral municipalities in this District. Agricultural land makes $58.6 \%$ of the total land area. There are 177 registered local com- 
munity offices and 77 municipal branch offices. $72.3 \%$ of the total number of persons employed work for some legal entity, while $27.7 \%$ are entrepreneurs and their employees. Unemployed first-time job seekers account for $26.6 \%$ (Statistical Office of the Republic of Serbia, 2014a).

Raška District covers an area of $3,923 \mathrm{~km}^{2}$. It includes 359 settlements. Total population is 308,386. The District is divided into 305 cadastral municipalities. Agricultural land makes $48.3 \%$ of the total land. There are 149 registered local community offices and 81 municipal branch offices. $70.2 \%$ of the total number of persons employed work for some legal entity, while 29.8\% are entrepreneurs and their employees. Unemployed first-time job seekers account for 51.1\% (Statistical Office of the Republic of Serbia, 2014a).

\section{Main characteristics of rural settlements belonging to the administrative unit the town of Čačak, their tourism infrastructure and products}

Territory of the Town of Čačak covers an area of $636 \mathrm{~km}^{2}$. This administrative unit has 58 settlements, 57 cadastral municipalities and the population of 114,141 people. There are 69 registered local communities and 29 municipal branch offices. $69.6 \%$ of the total number of persons employed work for some legal entity, while $30.4 \%$ are entrepreneurs and their employees. Unemployed first-time job seekers account for 26.2\% (Statistical Office of the Republic of Serbia, 2014a).

Villages belonging to the administrative unit the Town of Čačak that are the part of Rudnčka Morava microregion are very heterogeneous in terms of the number of inhabitants, households and development level. The basic characteristics of these settlements, in terms of geographical and social structure are as follows: altitude of the villages ranges from $187 \mathrm{~m}$ to $642 \mathrm{~m}$; population ranges from 57 to 2,761 people per village which makes a total of 28,252 people that live in 9,162 households in this microregion. The number of members per household ranges from 2.4 to 4 ; the number of registered farm businesses is 4,611, of which 3,543 are farms that are engaged in commercial production and 1,068 farms are non-commercial (Treasury of the Ministry of Finance, 2015). The population declined by 3,715 people compared to the 2002 census; rural economy and rural infrastructure are underdeveloped. 
Figure 1. Employment by main activity

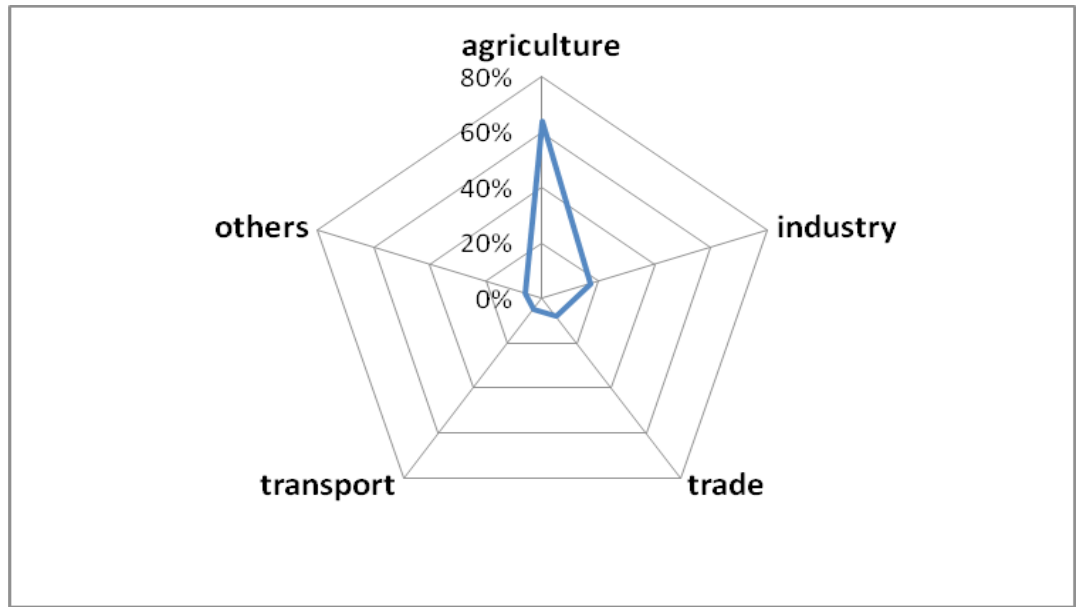

Source: Work of authors, based on research results.

Agriculture is the primary business activity in 26 rural settlements, while food processing industry is predominant only in 5 rural settlements (Figure 1). Due to the different level of development and the resources available, a single integral model of rural development cannot be applied to all areas (Njegovan, Crnokrak, 2012) - different development strategies and models must be combined. Those strategies that focus on recovery and revitalization, diversification and complementarity are the best strategies for rural development (Vasilevska, Ribar, 2007).

SWOT analysis of the rural settlements indicates that there are fewer weaknesses than strengths in terms of an integrated rural development and tourism development. Identified weaknesses may be significantly mitigated in the long term period through national development programmes, local initiatives and development of tourism value chain. Opportunities to be explored are related to the development of different forms of tourism, greater investments and more intensive development of households involved in tourism (Table 2).

Table 2. SWOT analysis of rural settlements

\begin{tabular}{|l|l|}
\hline Strengths & Weaknesses \\
\hline $\begin{array}{l}\text { - preserved rural landscapes of exceptional } \\
\text { beauty }\end{array}$ & \\
$\begin{array}{l}\text { - clean water, clean air, rich diversity of plants } \\
\text { and animals }\end{array}$ & $\begin{array}{l}\text { • poor diversification of business activities } \\
\text { - poor spatial and urban infrastructure } \\
\text { - hospitality }\end{array}$ \\
$\begin{array}{l}\text { - lack of funds } \\
\text { - adequate conditions for rural tourism } \\
\text { development }\end{array}$ & - lack of business initiative \\
\hline
\end{tabular}




\begin{tabular}{|c|c|}
\hline Opportunities & Threats \\
\hline $\begin{array}{l}\text { - valorization of cultural events and festivals } \\
\text { - improvement of institutional framework for } \\
\text { rural development } \\
\text { - utilization of funds given by rural development } \\
\text { funding programmes } \\
\text { - greater community participation in development } \\
\text { projects }\end{array}$ & $\begin{array}{l}\text { - inadequate development policy } \\
\text { - environmental pollution } \\
\text { - people leaving the villages } \\
\text { - insufficient professional and development } \\
\text { support services } \\
\text { - lack of interest to invest in tourism }\end{array}$ \\
\hline
\end{tabular}

Source: Work of authors, based on research results.

Tourism offer of Čačak and its surrounding villages is diverse thanks to various forms of tourism that are developed in this area. Cultural and historical monuments and archaeological sites are the subject of interest for many tourists. The Ovčar-Kablar Gorge of exceptional natural beauty together with its numerous monasteries (also called the Serbian Mount Athos) is the most attractive tourist destination. This region is also famous for its fertile soil, favorable climate, and drinking water of exceptional quality. Many rare plant species, as well as fruits and vegetables, are grown in this area. One of the best plum brandies in the world is made from plum varieties indigenous to Čačak, and this plum brandy is also the most famous brand from this region. By preserving cultural and historical heritage and folklore, the traditional crafts are also preserved making of opanak (traditional footwear in the villages of Eastern Europe), traditional folk costumes, pottery, icons, clothing and souvenirs. The town of Čačak is rich in sports facilities, which enables the development of sports and recreational tourism. Tourism organization of Čačak is the organizer and co-organizer of many tourist, cultural and sporting events; the most visited ones are Kupusijada (food festival dedicated to traditional dishes made of cabbage) in the village of Mrčajevci and the Gathering of the Serbian Flute Players in the village of Prislonica (Strategy for Sustainable Development of the Town of Čačak, 2011). Villages belonging to Rudnička Morava microregion clearly have substantial potential for development of rural tourism. Based on the existing resources, possible directions of tourism development are: spa tourism, cultural tourism, event tourism, religious tourism, sports and recreation, hiking, culinary tourism and ethno-tourism.

Accommodation capacity: According to the data of the Tourism Organization, the town of Čačak has several hotels (accommodation capacity 344 beds), several motels (60 beds), resorts (40 beds), B\&Bs - bed \& breakfast (27 beds) hostels (120 beds), boarding houses ( 54 beds), camps (34 beds) and also private accommodation (2,000 beds). In the village Prislonica, two households - the household of the family Pravdic and the household of the family Vićović are engaged in rural tourism; their accommodation capacity is 6 and 9 beds, respectively.

Overnight stays: 27,192 tourists were registered in Čačak in 2013, of which 18,325 were domestic tourists (67.4\%). Total number of overnight stays was 131,609 of which $78.6 \%$ were made by domestic tourists. The average length of stay was 5.6 days for domestic tourists and 3.3 days for foreign tourists. 9,814 tourists visited spa resort Gornja 
Trepča in 2013, of which 8,528 were domestic tourists (86.9\%). Total number of nights stayed was 104,300 , where $84 \%$ of overnight stays were made by domestic tourists. The average length of stay was 10.3 days for domestic and 13 days for foreign tourists (Statistical Office of the Republic of Serbia, 2014a).

\section{Main characteristics of rural settlements belonging to the administrative unit the town of Kraljevo, their tourism infrastructure and products}

Total area of the administrative unit the town of Kraljevo is $1,530 \mathrm{~km}^{2}$. This administrative unit consists of 92 settlements. There are 84 cadastral municipalities. There are 123,724 people living in this territory. $72.0 \%$ of the total number of persons employed work for some legal entity, while $28.0 \%$ are entrepreneurs and their employees. Unemployed first-time job seekers account for 31.9\% (Statistical Office of the Republic of Serbia, 2014a).

Villages belonging to the administrative unit the town of Kraljevo that are the part of Rudnička Morava microregion are characterized by the following: altitude of the villages spans a range from $181 \mathrm{~m}$ to $308 \mathrm{~m}$; population ranges from 651 to 1,125 people per village which makes a total of 3,841 people that live in 1,096 households; there are 816 registered farm businesses, of which 629 are farms that are engaged in commercial production and 187 farms are non-commercial (Treasury of the Ministry of Finance, 2015); the median age is 44.2 years; the population declined by 604 people compared to the 2002 census; the number of members per household ranges from 3.1 to 3.6. Rural economy and rural infrastructure are insufficiently developed.

Agriculture is the dominant activity and is followed by manufacturing, construction (especially in Tavnik), trade and transportation (Figure 2).

Figure 2. Employment by main activity

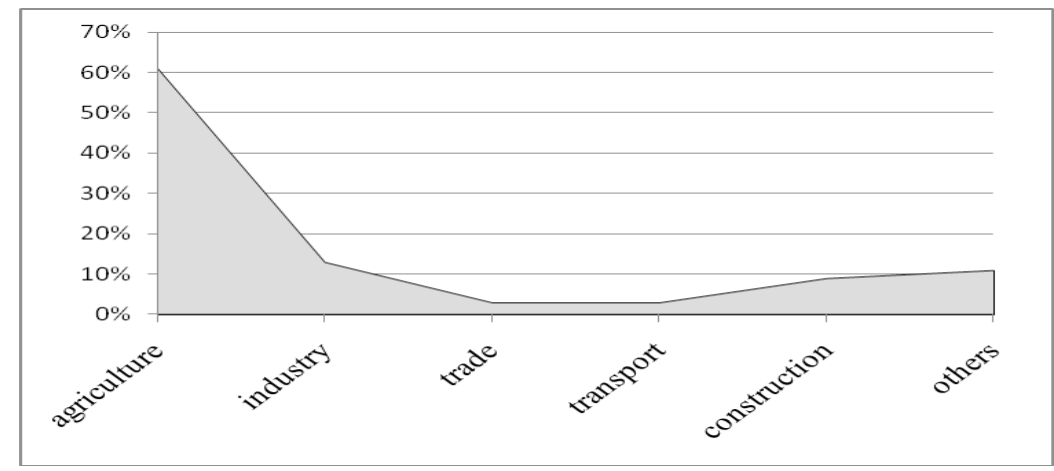

Source: Work of authors, based on research results.

SWOT analysis of the rural settlements belonging to the administrative unit the town of Kraljevo indicates that the moderate climate, favorable conditions for developing products with geographical indication, development of rural tourism products and other 
products associated with this type of tourism represent main comparative strengths, while major weakness arise from the present development situation of rural settlements and their communities (Table 3).

Table 3. SWOT analysis of rural settlements

\begin{tabular}{|c|c|}
\hline Strengths & Weaknesses \\
\hline $\begin{array}{l}\text { - } \text { natural resources } \\
\text { - } \text { tourism events } \\
\text { - resources for rural tourism development } \\
\text { - hospitality, openness and hedonism } \\
\text { - cultural and historical heritage }\end{array}$ & $\begin{array}{l}\text { - poor diversification of business activities } \\
\text { - poor infrastructure } \\
\text { - lack of funds } \\
\text { - lack of business initiatives } \\
\text { - unfavorable age structure }\end{array}$ \\
\hline Opportunities & Threats \\
\hline $\begin{array}{l}\text { - utilization of development funds } \\
\text { - economic diversification } \\
\text { - valorization of cultural events and festivals } \\
\text { - development of local action groups }\end{array}$ & $\begin{array}{l}\text { - lack of interest from local and foreign investors } \\
\text { - people leaving the villages } \\
\text { - lack of programmes to encouraging young } \\
\text { people to return to live in the villages } \\
\text { - environmental pollution }\end{array}$ \\
\hline
\end{tabular}

Source: Work of authors, based on research results.

Development strategies that would be best implemented in this region are those that focus on recovery and revitalization and accelerated development (Bogdanov, 2007), in order to prevent migration from rural areas, boost diversification of the rural economy, encourage the creation of new jobs and improve rural well-being. It should be noted that the goals of rural development can be both agricultural and non-agricultural (Dunay, 2011; Simonović, Milanović, 2005; Đekić, 2000), in this respect sustainable tourism allows optimal use of resources, while maintaining essential ecological processes and helps to preserve the natural heritage and biodiversity at the same time respecting the socio-cultural uniqueness of local communities.

Tourism offer: The town of Kraljevo has sufficient resources for development of different types of tourism. Thermal and thermal mineral springs are most important natural resources for tourism development. As far as the cultural tourism is concerned, this region is rich in cultural and historical monuments, as well as monasteries that date back to medieval times. Numerous tourist and sporting events are held in Kraljevo and the nearby villages: Days of Lilacs, Silver Cauldron, car and motorcycle races, white water rafting (on the Ibar River), the Annual Hiker Gathering, Art Colony, Classical Music Festival, International Jazz Festival, Art Festival, Days of Honey and Beekeeping, Daffodils Revisited, Bean Festival, Corn Bread Festival, Days of Football, children's and family festivals and etc. Rural tourism is more and more perceived as a form of escapism from the city life and return to nature. Tourists are given the opportunity to taste a wide range of local specialties, health food, famous cream from Kraljevo, cheese, fruit and vegetables, meat products, fruit brandies, etc. Villages Rudno, Lopatnica and Bogutovac are the leaders in terms of rural tourism development. Tourism offer is very diverse and attractive, thus, visitors can chose to go hunting, fishing, horseback riding, cycling, hiking along the marked trails, as well as to 
gather wild berries and medicinal plants, help with the work on the farm, help prepare meals, cook food preserve and the like. Villages near Kraljevo are also famous for their natural and artificial beaches on the riverbanks, swimming pools and swimming ponds, which are ideal places for relaxation, entertainment and recreation during the summer months. Several households in the village of Rudno are engaged in rural tourism, these are: the household of Škeler family, the household of Dragan and Radina Milošević, the household of Predrag Ćirović-Peda and the household of Slađana Milikić-Sretović. Two households are engaged in rural tourism in the village of Lopatnica - the household of Ljubomir Milojević and the household of Gorana Vukićević. Ethno Village Bogut owned by Jovica and Darinka Filipović is situated in the village of Bogutovac. Villages near Kraljevo that belong to Rudnička Morava microregion have sufficient resources for development of rural, cultural, event, recreational and religious tourism, and they should be given priority in terms of the future development programmes. The economy of these villages is diversified, i.e. there are enterprises, grocery stores, craftsmen's shops, retail stores, bars and restaurants. Church of the St. Paul the Apostle is situated in Cvetke village and Monastery Voljavča is situated in Tavnik village. Art Colony and the Annual Horse Pulling event are held in Cvetke village, while Folk Music Festival and sports tournaments are regularly organized in Lađevci village. Based on the available resources, the possible directions of tourism development in this area are: spa tourism, hiking, cultural events and festivals, sports and recreation, adventure tourism, culinary tourism and rural tourism (Development Strategy of the Town of Kraljevo, 2015).

Accommodation capacity: Kraljevo has a large number of accommodation facilities. Namely, hospitality establishments and facilities have a total of 2,176 beds. The greatest accommodation capacity is that of spa resort Mataruška Banja ( 980 beds), followed by spa resort Bogutovačka Banja (545 beds), Goč (450 beds) and the town of Kraljevo with 140 beds (Development Strategy of the Town of Kraljevo, 2015).

Overnight stays: 25,368 tourists were registered in Kraljevo in 2013, of which 19,704 were domestic tourists (77.7\%). Total number of overnight stays was 118,738, of which $90.6 \%$ were made by domestic tourists. The average length of stay was 5.5 days for domestic and 2 days for foreign tourists (Statistical Office of the Republic of Serbia, 2014a).

\section{Development of key tourism products, infrastructure and destination marketing}

In terms of the next development period and based on the aforementioned, one can confidently say that Rudnička Morava microregion will strengthen its position on the tourism market through creation of distinctive, modern tourism product, adequate infrastructure, branding and improvement of the overall service quality of this destination. However, it is necessary to functionally connect this microregion with neighboring towns, cities and resorts. With this in mind, it is important to support the programmes/projects related to preserving local traditions and customs and local cuisine through improvement of existing traditional festivals; carry out valorization of forest resources in order to include them in the tourism offer; develop hunting tourism; develop birdwatching tours; build new recreation trails; build accommodation 
facilities in the authentic villages; and work intensively on education and development of tourism.

Rudnička Morava, as a tourist destination, should build its long-term market position by taking into account the following aspects of the tourism market infrastructure: the need for innovation, differentiation and specialization; education, staff training and development and overall improvement of the service quality; development of destination management systems; branding of local delicacies; participation of local healthy food producers in distribution of products; food product innovation; modernize and improve local hospitality facilities serving food and beverages; organize various workshops for tourists; establish visitor information center; improve and protect older locations and settlements; put up information signs and signposts.

Advertizing and promotion of Rudnička Morava are among the most important tourism development processes and are important determinants of tourism development in this microregion. In this regard, it is necessary to improve all aspects of tourism promotion that boost tourism development. People who live on the territory of Rudnička Morava and have relevant knowledge and qualifications, as well as sufficient experience, should play an important role in tourism development and promotion. In the context of further development of Rudnička Morava as a tourist destination, it is necessary to establish an adequate marketing system which includes at least four major areas, namely: marketing infrastructure and branding programmes; sales and commercialization systems; communication systems; and internal marketing.

\section{Positions of the key stakeholders on the effect of tourism on the development of rural areas}

Survey research was used to assess the attitudes of the respondents, for which purpose e-mail survey and personal interviews were conducted.

a) Results of the research on the attitudes of tourists:

Survey on the attitudes of tourists was conducted in order to identify elements of the tourism offer that should be improved so as to make this destination recognizable on the tourism market. The questionnaire is divided into two parts: the first part establishes the age structure, educational level and demographic structure of the respondents, while the second part of the questionnaire examines whether the respondents already visited this destination and what were the motives of their visit, as well as measures the level of their overall level of satisfaction. 
Figure 3. Gender structure of the respondents

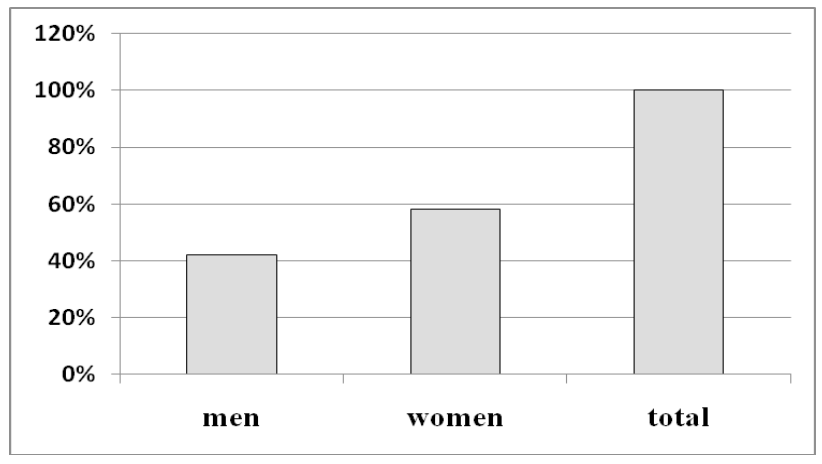

Source: Work of authors, based on research results.

In terms of the gender structure, of the total number of 60 people surveyed $58 \%$ are women (Figure 3).

The most common age group is that between 36-55 years, while the persons over 65 years of age are in the the least represented age group. The population aged 18-45 years makes $53 \%$ of the total number of respondents, $37 \%$ are people between $46-65$ years of age, while people over 65 years represent only $10 \%$ of the sample (Figure 4).

Figure 4. Age structure of the respondents

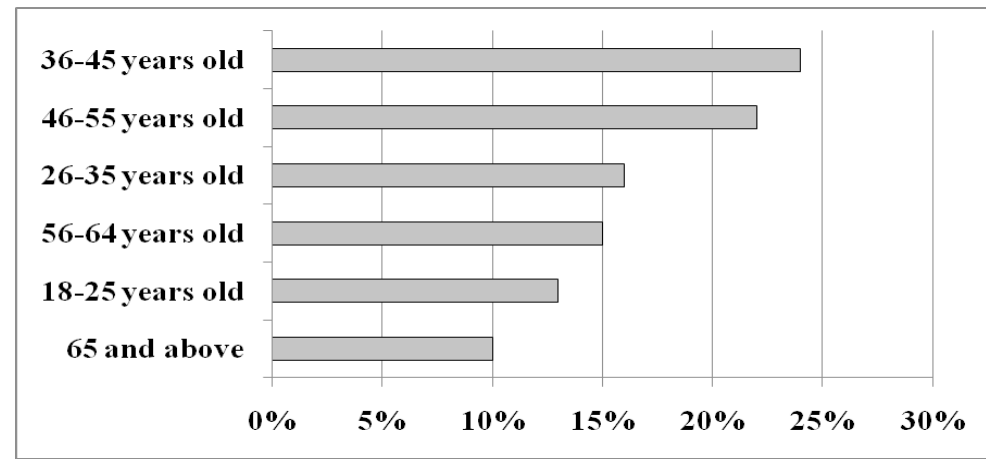

Source: Work of authors, based on research results.

In terms of the level of education, the largest percentage of respondents have completed secondary education (36\%), then follow the respondents with university degree (32\%), while $27 \%$ of respondents completed some college.

The majority of respondents (52\%) described themselves as persons interested in learning about new places and enjoying beauty of nature, $17 \%$ tourists interested in sports and recreational tourism, $13 \%$ culinary tourists, tourists interested in history and cultural heritage $10 \%$, environmentally motivated tourists $8 \%$ and others. The largest percentage of respondents $-65 \%$ are new visitors, i.e. they visited this destination for the first time, while others are returning visitors who visited this destination between EP 2016 (63) 2 (665-680) 
two and five times. As for the length of stay, 53\% of respondents stayed for just two days, while $30 \%$ of respondents stayed for 10 days. The rest of the respondents stayed for more than 10 days. Of the total number of the respondents, $83 \%$ are self-organized tourists, while $17 \%$ use the services of some travel agency. The majority of visitors come with their friends and family - 72\%. Most of the respondents learnt about this destination from articles in newspapers and magazines (27\%), $21 \%$ were informed by word of mouth (usually from friends and relatives), Internet (20\%), brochures (18\%) or some other information source.

Average rating of the respondents' overall experience and the level of satisfaction during their visit on a scale of 1 to 5 is 3.56, therefore, it can be concluded that the respondents were generally satisfied. However, they were less satisfied with the following: souvenirs and local products, diversity of tourism products and infrastructure. They enjoyed in preserved environment, natural and cultural-historical heritage, hospitality of their hosts, food and beverage offer.

b) Results of the research on the attitudes of tourism organizations:

Tourism organizations on the territory of Rudnička Morava were surveyed primarily in order to determine their attitudes and opinions on the opportunities for development of tourism products in the region. Here are the results of the research:

- Tourism organizations put first event tourism and consider it the most important tourism product; then follow rural tourism, culinary tourism, cultural tourism, ecotourism, sports and recreation and hunting tourism;

- rural tourism, according to the views of tourism organizations, is less developed compared to other forms of tourism, although there are significant natural and human resources which are increasingly used for tourism development;

- Tourism organizations rate accommodation facilities in rural areas as unsatisfactory and are of the opinion that these should be significantly improved;

- according to the tourism organizations, cultural resources, including events and rich cuisine are solid basis for development of rural tourism;

- Tourism organizations identify the following as the main constraints in terms of development of rural tourism products: lack of funds and motivation for starting a tourism business, overlooking good practice examples and failing to register guests that tourism organizations send to rural households, infrastructure issues in villages, inadequate resources of the local community offices to stimulate tourism development.

c) The results of the research on the attitudes of rural tourism households are as follows:

Survey included 10 rural households and was conducted to determine their attitudes and opinions on the constraints and opportunities for development of rural tourism. The 
obtained results indicate the following:

- in recent years there is an increase in the number of households that decide to become rural tourism providers;

- the dominant age structure for persons in this region is ages $35-50$ years $(60 \%)$;

- income from tourism and agriculture are the primary source of income for $40 \%$ of the surveyed households, while for other $60 \%$, tourism, salaries paid by some employer and pensions are the primary source of income;

- the majority of households started their rural tourism businesses by investing their own savings and assets as the initial capital (80\%);

- $70 \%$ of households see the small number of guests and the problems related to adaptation, registration and categorization of accommodation facilities as the main problem when starting the rural tourism business;

- $80 \%$ of respondents intend to expand the business in the future, primarily by investing in increasing the accommodation capacity or opening ethnic restaurants;

- most surveyed households rent 2-4 rooms to guests and these are mostly double rooms;

- all surveyed households offer accommodation and food services, also, guests are given the opportunity to buy or make some home-made products during their stay (fresh fruits and vegetables, different kinds of jams, fruit preserves, roasted pepper spread (ajvar), brandy, juices, meat products, eggs, cheese, cream, honey, wine, etc.) as well as handicraft products;

- most surveyed households had 100 to 500 overnight stays a year made primarily by domestic tourists from urban centers;

- most respondents completed some educational seminar in the field of rural tourism and they confirm that they could put into practice what they learned; some of the respondents attended some educational course abroad which they found useful.

\section{Conclusion}

Rudnička Morava microregion is an area of very favorable natural resources for tourism development. Climate characteristics, geographical configuration and altitude allow the development of quality tourism products. Existing natural and cultural resources provide an opportunity for the development of year-round and diversified supply of tourism products; despite this tourism does not generate the expected economic effects. Entrepreneurial initiatives are the key to the successful development of tourism, as well as willingness of the investors to invest their funds in various projects and cooperation of the key development actors. Administrative and legal mechanisms regulating environmental protection are very important for the implementation of strategies for sustainable tourism development in this microregion. The condition of general and 
tourism infrastructure must be continuously improved, as well as economic status of rural settlements. The lack of organized sale of local products and souvenirs indicates that a particular trading area should be established where handicrafts, souvenirs and products with protected designation of origin would be sold and which would adequately meet the tourists' demand for certain products and local produce. Due to the great tourism potential, the authorities must see that all cultural and historical monuments in this area are put under the highest level of protection, also, they must strictly control the processes of conservation of these monuments. The use of natural resources must be strictly controlled, particularly granting of concessions for use of natural resources for tourism purposes. Local governments have the primary task to create attractive conditions for attracting new investors and are responsible for establishing an adequate control mechanism which will ensure a balance between the three pillars of sustainable development - environmental protection, economic development and social development. And, to conclude this topic, it is vital to stress the role of tourists in the sustainable development of tourist destination Rudnička Morava.

\section{Literature}

1. Bogdanov, N. (2007): Mala ruralna domaćinstva u Srbiji $i$ ruralna nepoljoprivredna ekonomija, UNDP - Program Ujedinjenih nacija za razvoj, Beograd, Srbija, (available at: http://ruralinfoserbia.rs/publikacije/undp_mala_ ruralna_domacinstva.pdf).

2. Bogdanov, N., Zečević, B., Versaci, A., Rohac, J. (2011): Javno-privatno partnerstvo u ruralnom turizmu, UNDP - Program Ujedinjenih nacija za razvoj, Beograd, Srbija.

3. Uprava za trezor Ministarstva finansija Republike Srbije (2015): Broj registrovanih poljoprivrednih gazdinstava, Beograd, Srbija.

4. Buhalis, D., Costa, C. (2006): Tourism business frontiers, Butterworth-Heinemann Elsevier, Oxford, United Kingdom.

5. Cozac, E. (2012): The importance of rural tourism development in rural communities, in Fascucula: Ecotoxicologie, Zootehnie şi Tehnologii de Industrie Alimentară, pp. 19-22, Analele Universității din Oradea, Oradea, Romania, (available at: http://protmed.uoradea.ro/facultate/anale/ecotox_zooteh_ind alim/2012A/imapa/07.Cozac\%20Elena.pdf).

6. Đekić, S. (2000): Agrarni i neagrarni aspekti ruralnog razvoja, Ekonomski horizonti, vol. 2, no. 1-2, pp. 53-59, Ekonomski fakultet Univerziteta u Kragujevcu, Kragujevac, Srbija, (available at: http:/www.horizonti.ekfak.kg.ac.rs/sites/ default/files/casopis/2000/4_Snezana_Djekic.pdf).

7. Dunay, A. T. (2011): Development of rural areas through the CAP 2020 and Europe 2020 strategies, Szent István University, Gödöllő, Hungary, (available at:http://www.wne.sggw.pl/czasopisma/pdf/PRS_2011_T11\%2826\%29_z3_s161. pdf).

8. Košić, K., Demirović, D., Pejanović, R., Lazić, L., Stamenković, I. (2015): Key principles of rural tourism households development strategy - case of Vojvodina, Ekonomika poljoprivrede, vol. 62, no. 4, pp. 975-989, The Institute 
of Agricultural Economics, Belgrade, Serbia (available at: http://bsaae.bg.ac.rs/ images/Ekonomika\%20kompletna/2015/EP\%20-\%204\%20-\%202015\%20-\%20 \%20final.pdf).

9. Njegovan, Z., Crnokrak, N. (2012): Ruralni razvoj u ekonomskim teorijama razvoja, Agroprivreda Srbije u pretpristupnom periodu, DAES - Društvo agrarnih ekonomista Srbije, Beograd, Srbija, pp. 89-109, (available at: http://portal.zzbaco. $\mathrm{com} / \mathrm{mojo} \mathrm{baco} / \mathrm{Data} / \mathrm{Sites} / \mathrm{1} /$ thematicproceedings agrarianeconomyofserbia.... pdf).

10. Pejanović, R., Vujović, S. (2008): Ruralni razvoj i agroturizam, Agroekonomika, no. 37-38, pp. 5-15, Poljoprivredni fakultet Univerziteta u Novom Sadu, Novi Sad, Srbija, (available at: http://agroekonomika.rs/images/arhiva/ agroekonomika_37-38.pdf).

11. Republički zavod za statistiku (2014a): Opštine i regioni u Republici Srbiji 2014, Beograd, Srbija, (available at: http://pod2.stat.gov.rs/ObjavljenePublikacije/ G2014/pdf/G20142014.pdf).

12. Republički zavod za statistiku (2014b): Statistički godišnjak Republike Srbije 2014, Beograd, Srbija, (available at: http://pod2.stat.gov.rs/ObjavljenePublikacije/ G2014/pdf/G20142013.pdf).

13. Saarinen, J., Lenao, M. (2014): Integrating tourism to rural development and planning in the developing world, Development Southern Africa, vol. 31, no. 3, pp. 363-372, Routledge Taylor \& Francis, Abingdon, Oxon, United Kingdom.

14. Simonović, Z., Milanović, R. (2005): Neki ekološki problemi poljoprivredne proizvodnje i ruralnog razvoja, Multifunkcionalna poljoprivreda i ruralni razvoj, Institut za ekonomiku poljoprivrede, Beograd, Srbija.

15. Strategija održivog razvoja grada Čačka, Skupština grada Čačka, 2011, Čačak, Srbija (available at: http://www.cacak.org.rs/userfiles/files/Nacrt\%20 Strategije\%20odrzivog\%20razvoja\%20grada\%20Cacka.pdf).

16. Strategija razvoja grada Kraljeva 2015-2020, Skupština grada Kraljeva, 2015, Kraljevo, Srbija, (available at: http://www.kraljevo.rs/wp-content/ uploads/2015/10/STRATEGIJA-RAZVOJA-GRADA-KRALJEVA.pdf).

17. Štetić, S., Šimičević, D. (2008): How to develope sustainable tourism in rural destinations in Serbia, Bulletin of the Serbian Geographical Society, vol. 4, no. 4, pp. 19-28, Serbian Geographical Society, Belgrade, Serbia, (available at: http:// www.doiserbia.nb.rs/img/doi/0350-3593/2008/0350-35930804019S.pdf).

18. Todorović, M., Bjeljac, Ž. (2007): Osnove razvoja ruralnog turizma u Srbiji. Glasnik Srpskog geografskog društva, vol. 1, no. 1, pp. 135-148, Srpsko geografsko društvo, Beograd, Srbija, (available at: http://www.doiserbia.nb.rs/ img/doi/0350-3593/2007/0350-35930701135T.pdf).

19. Todorović, M., Štetić, S. (2009): Ruralni turizam, Geografski fakultet Univerziteta u Beogradu, Beograd, Srbija.

20. Turistička organizacija Čačka, (available at: http://turizamcacak.org.rs/)

21. Turistička organizacija Kraljeva, (available at: http://www.jutok.org.rs/)

22. Udovč, A., Perpar, A. (2007): Role of Rural tourism for development of rural 
areas, Journal of Central European Agriculture, vol. 8, no. 2, pp. 223-228, Faculty of Agriculture - University of Zagreb, Zagreb, Croatia, (available at: https://jcea. agr.hr/articles/471_ROLE_OF_RURAL_TOURISM_FOR_DEVELOPMENT OF_RURAL_AREAS_en.p̄pdf).

23. Vasilevska, Lj., Ribar, M. (2007): Strateški pristup ruralnom razvoju - prednosti i ograničenja primene dopunskih aktivnosti, Vlasinski susreti 2007-Tradicionalno i savremeno u radu i životu ljudi u selu, Srpsko udruženje za sociologiju sela i poljoprivrede, Zavod za proučavanje sela, Balkanska asocijacija za sociologiju sela i poljoprivrede, Beograd, Srbija, pp. 200-210.

\title{
TURIZAM KAO FAKTOR ODRŽIVOG RAZVOJA RURALNIH PODRUČJA RUDNIČKE MORAVE
}

\author{
Lela Ristič ${ }^{4}$, Milan Vujičičs, Miljan Lekovićc
}

\begin{abstract}
Rezime
Predmet istraživanja ovog rada je turizam, kao esencijalna komponenta održivog ruralnog razvoja područja Rudničke Morave. Cilj rada je da se, na osnovu analize modela ruralne razvijenosti na ovom području, ukaže na ulogu turizma u integraciji ruralnih oblasti u nacionalnu i međunarodnu ekonomiju, sa stanovišta efikasnijeg endogenog razvoja. Osnovna hipoteza od koje se polazi je da ruralna područja Rudničke Morave raspolažu značajnim prirodnim i antropogenim resursima za razvoj turizma, ali nedostaju integrisane strategije za njegov održivi doprinos jačanju konkurentnosti ruralne privrede. Sobzirom na predmet, cilj i postavljene hipoteze, u radu je primenjena kvalitativna, kvantitativna i SWOT analiza, a za istraživanje stavova ključnih aktera razvoja turizma korišćen je anketni metod. Rad je strukturiran u osam delova. Ključni rezultat istraživanja je ukazivanje na neophodnost stavljanja fokusa na razvoj ruralnog turizma, kao bitne komponente revitalizacije sela i lokalnih zajednica.
\end{abstract}

Ključne reči: održivi turizam, ruralni razvoj, turistički proizvodi, marketing sistem destinacije, Rudnička Morava.

4 Vanredni profesor, dr Lela Ristić, Univerzitet u Kragujevcu - Ekonomski fakultet, Ulica Đure Pucara Starog br. 3, 34000 Kragujevac, Republika Srbija, Telefon: +381 603348719 , E-mail: 1ristic@kg.ac.rs

5 Dr Milan Vujičić, Univerzitet u Kragujevcu-Filološko-umetnički fakultet, Ulica Jovana Cvijića bb, 34000 Kragujevac, Republika Srbija, Telefon: +381 603377 404, E-mail: vujicicm@yahoo.com

6 Asistent, Miljan Leković, Univerzitet u Kragujevcu - Fakultet za hotelijerstvo i turizam u Vrnjačkoj Banji, Vojvođanska bb, 36210 Vrnjačka Banja, Republika Srbija, Telefon: +381 6435823 04, E-mail: m.lekovic@,kg.ac.rs 